\title{
Aleksandr Bogdanov's Sociology of the Arts
}

\author{
JOHN BIGGART \\ independent scholar, United Kingdom; ramishvili@protonmail.com \\ Commentary by CHRIS READ
}

Keywords: Aesthetics, Arvatov, Collectivism, Hamlet, Marx, Mentalité

\begin{abstract}
Aleksandr Bogdanov's theory of culture has been outlined in a number of key works on his life and work. 'The purpose of the present article is to situate his ideas on the social function of the arts within the framework of his theory of culture. I point out that, whereas in his general theory of social consciousness Bogdanov acknowledged his indebtedness to Marx, he considered that in respect of the arts he had improved on Marx, who had viewed the arts as a mere "embellishment of life". I argue that for Bogdanov, "proletarian culture" was not the working class "mentalité" of his time, but a state of mind that with the assistance of his brainchild, the Proletarian CulturalEducational Organization, would evolve in the direction of a collectivist, "all-human", culture. I explain that the didacticism of this approach antagonized a number of writers of proletarian origin. This article is based on works by Bogdanov, few of which have been re-published in post-Soviet Russia and most of which are not available in other languages. It will enable culturologists and other scholars to include Bogdanov in the history of the sociology of the arts, an exercise that has hitherto been impeded by Soviet censorship of his works, under-tuition of the Russian language, and a scarcity of relevant translations.
\end{abstract}

\section{Bogdanov, Marx, and the social function of the arts ${ }^{2}$}

Writing on the relationship between thinking and economic activity, Friedrich Engels, in a letter to Joseph Bloch of 1890, pointed out that Marx's understanding of this relationship was not to be understood as a form of uni-directional determinism. "The economic situation", he wrote, "is the basis, but the various elements of the superstructure ... political, juristic, philosophical theories, religious views, and their further development into systems of dogmas - also exercise their influence upon the course of the historical struggles and in many cases preponderate in determining their form." ${ }^{3}$ We do not know whether Bogdanov had read this letter, but Engels's clarification was in any case consistent with Bogdanov's own understanding of Marx, as he made clear in a number of his philosophical

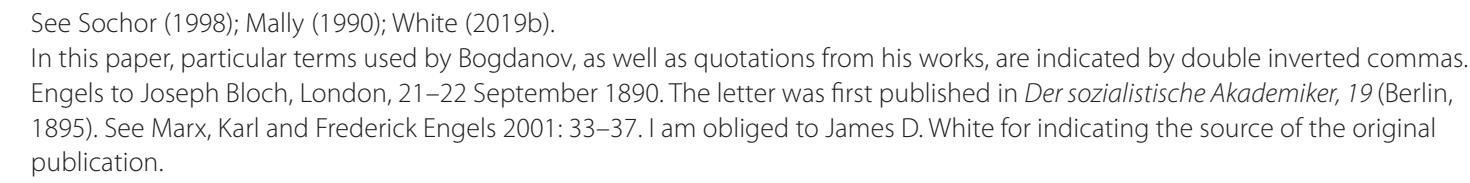


writings. For example in The Philosophy of Living Experience (Bogdanov 1913b) he cited Marx's third 'Thesis on Feuerbach' of 1845 (Feuer 1959), where Marx had asserted that "it is human beings who change circumstances, and ... the educator also needs educating". Society was not divided into two parts: "The coincidence of the changing of circumstances and of human activity can be conceived and rationally understood only as revolutionizing practice."4 Bogdanov, who insisted that he was an "historical materialist" (Bogdanov 1923a), ${ }^{5}$ at the same time considered Marx to have been "a great forerunner" of his own organization science (Bogdanov 1996: 104). However, when it came to the social function of the arts he disagreed with Marx, who, he alleged, had viewed art as a mere "embellishment of life"."

By the eve of the First World War, Bogdanov had developed a sociology of ideas that was grounded in his 'empiriomonist' epistemology, in an evolutionist history of social formations, and in a general theory of the dynamics of organization, equilibrium and change in nature, thinking and society. In works written before 1917, when he came to deal with the function of ideology in society, he would frequently draw examples from the history of the arts. He considered that the slogan of 'proletarian culture' had first been introduced into socialist theory at the Party School organized by the Forward group (Vpered) of the Russian Social Democratic Workers' Party on the island of Capri in 1909, and in 1914 he had written in an article intended for the journal Nasha zarya that "art was one of the ideologies of a class - an element of its class consciousness." ${ }^{8}$ However, this article was not published and it was not until the founding of the Proletkult in September 1917 that Bogdanov began to produce a body of work that focused specifically upon the social function of the arts. ${ }^{9}$ The present paper will draw upon two of Bogdanov's general works on ideology that were published before the First World War, The Philosophy of Living Experience. A Popular Outline (Bogdanov 1913b); ${ }^{10}$ and The Science of Social Consciousness. A Short Course in Ideological Science in Questions and Answers (Bogdanov 1914). ${ }^{11}$ It will also make use of the articles that Bogdanov gathered for the anthology On Proletarian Culture 19041924 (Bogdanov 1924/1925), most of which were written during the Proletkult period. Bogdanov's utopian novel Red Star (Bogdanov 1908) and his Tektology. A General Organizational Science, the first part of which was published in 1913, also provide insights into his understanding of the arts. ${ }^{12}$

\section{History as the evolution of ideologies}

It was in 1906 that Bogdanov for the first time outlined his understanding of the progression of social formations - from "authoritarian", through "individualistic", to "collectivist", in the $7^{\text {th }}$ edition of his Short Course on Economic Science (Bogdanov 1906). This overview was also provided in The Philosophy of

4 Georgii Gloveli has pointed out that M. Filippov, the editor of Nauchnoe Obozrenie, had noted the 'sociological'as distinct from 'economistic' determinism of Marx as early as 1897. See Gloveli 2009: 54-57.

5 Thesis No. XI (1923) in Bogdanov 2003: 461-462.

6 Bogdanov summarized what he considered to be the shortcomings of Marxist theory in Part I of Tektology. He explicitly rejected Marx"s understanding of art as a mere "embellishment of life" ("iskusstvo schital prostym ukrasheniem zhizni"). See Bogdanov 2003: 80-81. Whether his understanding of Marx on this point was correct is a question that need not concern us here. See, on this question, Rose 1994. Bogdanov had been the General Editor of a new translation by V. A. Bazarov and I. I. Skvortsov-Stepanov of Marx's Capital, published in 1907 and 1909. However, many of Marx's works did not become available until after Bogdanov's death; for example the Grundrisse der Kritik der politischen Ökonomie was not published in the Soviet Union until 1939. On the general question of the reception of Marx in Russia, see White 2019a and 219b.

7 See Bogdanov 1901, 1904 and 1904-1906 [and translation 2020]. For a review of Bogdanov's works on philosophy, see Steila 1996 and 2013 ; and White 2019a. and 2019b.

8 See "Vozmozhno li proletarskoe iskusstvo?" (1914), in Bogdanov 1924/1925: 204-216. Bogdanov does not here state that he disagrees with Marx. The article formed part of a polemic with G.A. Aleksinskiy and A.N. Potresov, who had argued in Nasha zarya (1913) that art was an indulgence of the leisure class.

9 On the Proletkult, see Sochor 1988, Chapter 6, "School of Socialism: Proletkult"; and Mally 1990.

10 The third edition of 1923 included the Appendix "From religious to scientific monism", a concise version of a lecture Bogdanov had delivered to the Institute of Scientific Philosophy in February 1923.

11 The author's preface is dated 16 November 1913. I have used the edition republished in Bogdanov 1999: 261-470

12 See Bogdanov 1913a. The author's preface to this first part is dated 15/28 December 1912. 
Living Experience (1913) and The Science of Social Consciousness (1914). Inverting what would have been the usual explanatory structure for a Marxist historian, Bogdanov characterized each period in terms of its predominant "world view" (mirovozzrenie) or "ideology" and only then went on to describe the technical, economic and social conditions that corresponded to each of these ideologies. The earliest period was that of "primeval ideologies" (pervobytnye ideologii). This was the period of hunter-gatherer societies when humans first acquired speech, and which were characterized by a primitive, inchoate and conservative collectivism, which Bogdanov hesitated even to qualify as a "world-view". Next came the period of "authoritarian ideologies", which was divided into successive sub-periods of "patriarchal ideology", corresponding to the early development of agriculture and nomadic livestock husbandry; and "feudalism", characterized by settled agriculture and livestock farming, the development of implements and the growth of trade. Then came "individualistic ideologies", typical of societies of small producers practicing commodity exchange but also of such transitional forms as i) the slave-owning societies of the classical world, ii) serfdom, iii) craft-workshop economies and iv) commercial capitalism. The ultimate (and emergent) ideology, Bogdanov argued, would be "Collectivism". As he put it very concisely, in 1918: "The spirit of authoritarianism, the spirit of individualism, the spirit of comradely solidarity (tovarishchestvo) - these are the three types of culture."13 This linear-evolutionist interpretation of history was fundamental to Bogdanov's understanding of proletarian culture in general and of the arts in particular.

For Bogdanov, the special function of the arts (viewed as one of a number of expressions of the ideology of any given social formation), was that of cognition in the realm of sensory experience. In ancient times people had acquired their understanding of the world in the form of myths. With the development of philosophy and science, cognition had acquired instruments suited to dealing with abstract thought, but art had retained the function of contributing to a world view through the organization of the feelings. As with other modes of cognition, the social function of the arts was not passive; on the contrary, they provided "social education": whereas, in the past, this function had been performed by cave drawings, epic poetry or religious myths, ${ }^{14}$ in more recent times, belles lettres (the novel, drama, poetry) and the visual and plastic arts all served as a "schooling in life".15

\section{Art in the transition to Collectivism ${ }^{16}$}

It was the advent of machine production that had provided the pre-conditions for the formation of a collectivist world view:

"The gathering of the proletariat in the cities and factories has a great and complicated influence upon the proletarian psyché. It gives rise to the realization that in labour, in the struggle with the elements for existence, the individual is only a link in a great chain ... The individual 'Ego' is cut down to size and put in its place." No less importantly, since machine work required the exercise of both hand and brain, the functions of 'management' and 'implementation', hitherto separate, and mediated through relations of authority and subordination, were now combined in "a fellowship of cooperation (sotrudnichestvo), which is the principle upon which the proletariat constructs its organization."17

13 "Chto takoe proletarskaya poeziya?" (1918), in Bogdanov 1924/1925: 137.

14 Among Bogdanov's favourite examples were the Mahabharata; the works of Homer and Hesiod and the Hebrew Bible. In architecture, the Coliseum in Rome was a metaphor for the pride and cruelty of an imperial people; the Gothic cathedral a metaphor for the world view of the Middle Ages - the rejection of this earth and striving towards the after-life. See Bogdanov 1911, 14-18; and "Proletariat i iskusstvo" (Speech to the First All-Russian Conference of the Proletkult, 20 September 1918), in Bogdanov 1924/1925: 117-118.

15 See "Sotsial'no-organizatsionnoe znachenie iskusstva" - Theses for a lecture delivered by Aleksandr Bogdanov to the Russian Academy of Artistic Sciences, 29 October 1921", RGALI, f.941, op.1., ed. khr.3, in Bogdanov 2004: 5-9.

16 On 'Collectivism', see Sochor 1988: 136-138; and White 2019, 198-199

17 "Chto takoe proletarskaya poeziya?" (1918) in Bogdanov 1924/1925: 136. See also the section "Tekhnicheskie i ekonomicheskie osnovy kollektivizma" in Nauka ob obshestvennom soznanii (1914) in Bogdanov 1999: 446-452. 
However, whilst collectivism would be the world-view of all humanity in the future, it was not yet the outlook of a working class that, for all its political and economic progress in both Western Europe and Russia, still remained culturally backward. The idea that the working class was culturally backward was central to Bogdanov's theory, and he only ever spoke of embryonic "elements" of proletarian culture being present in the art and literature of his day. ${ }^{18}$ In 1914 he cited the poem of Aleksey Mashirov-Samobytnik, "To a new comrade" (Novomu tovarishchu), and in 1918 the same writer's "To my fellow brethren" (Moim sobrat'yam), as examples of "emerging" (sic) collectivism. ${ }^{19}$ He found only "elements" of proletarian culture in the work of Aleksey Gastev, "Factory sirens" (Gudi) and Vladimir Kirillov, "To the times that lie ahead" (Gryadushchemu). ${ }^{20}$

\section{The artist - an integral member of the collective}

Given the backwardness of the working class, how would proletarian art evolve? It was incumbent upon both the artist and the critic to select and utilize from the art of the past and of the present, that which could be of benefit to the proletariat and to reject that which was potentially harmful. ${ }^{21}$ In July of 1918 Bogdanov seemed to suggest that this evolution would be a natural, self-regulating, organic process, akin to natural selection: "the artist can give the most harmonious arrangement to his living images when he does so freely, without compulsion or direction ... The content of art is life without restrictions or prohibitions."22 However, this did not mean that the artist functioned in isolation from society: in August 1918 he described the incorporation of art into ideology as an interactive process (vzaimnaya svyaz', literally, 'reciprocal link'). ${ }^{23}$ The artist's selection of images was regulated in the first instance by self-criticism, as the artist strove to eliminate from a work everything that was not in harmony with its central idea. There followed a process of spontaneous regulation (regulirovanie) by society, through the explicit, conscious criticism of the work of art from a class point of view. ${ }^{24}$ Bogdanov made this point concisely in his speech to the First All-Russian Conference of the Proletkult on 20 September 1918: "The artistic talent is individual, but creation is a social phenomenon: it emerges out of the collective and returns to the collective, serving its vital purposes."25

\section{The paradox of "tektological selection"}

Bogdanov insisted that he was not merely applying Darwin's theory of natural selection to the social sphere. He maintained that evolutionary biology was mistaken in distinguishing rigidly between natural selection (otbor) and artificial selection. This distinction, he tells us, disguised the existence of an overarching tektological selection mechanism (podbor) that was also at work in economic, social

18 For Bogdanov, the capitulation of the working classes to the bourgeoisie during the World War had amply demonstrated the immaturity of its outlook. See "1918", in Bogdanov 1924/1925: 101; and "O khudozhestvennom nasledstve" (1918), Bogdanov 1924/1924: 144-145. On this point, see Sochor 1988: 95 and White 2013: 52-70.

19 See "Vozmozhno li proletarskoe iskusstvo?" (1914) and "Proletariat i iskusstvo" (1918) in Bogdanov 1924/1925: 111-112 \& 119.

20 The poems of Gastev and Kirillov are cited in "Chto takoe proletarskaya poeziya?" (1918), in Bogdanov 1924/1925: $139-140$.

21 "1918" ("Ot redaktsii"), Proletarskaya kul'tura, No.1 (July 1918), in Bogdanov 1924/1925: 102. See also Bogdanov 1920 : 14.

22 "Chto takoe Proletarskaya poeziya?", Proletarskaya kul'tura, No.1 (July, 1918), in Bogdanov 1924/1925: 129.

23 See also Bogdanov's explanation of how a critique of religion would reveal the reciprocal mechanism that linked ideology and social development, in "O khudozhestvennom nasledstve", Proletarskaya kul'tura, No.2 (July, 1918), and Bogdanov 1924/1925: 149. See also "Puti proletarskogo tvorchestva. Tezisy" (1920), in Bogdanov 1924/1925: 199. These theses, prepared for the First All- Russian Congress of the Proletkults, were originally published in Proletarskaya kul'tura, Nr.13/14 (January-March) and Nr.15/16 (April-July) 1920. Further theses on artistic technique, from a lecture that had been delivered in May 1920 to a Conference of Proletarian Writers, were included in Bogdanov's anthology of 1924/1925.

24 "Kritika proletarskogo iskusstva", Proletarskaya kul'tura, Nr.3 (August, 1918), in Bogdanov 1924/1925: 158.

25 "Proletariat i iskusstvo" (Speech to the First All-Russian Conference of the Proletkult, 20 September 1918), in Bogdanov 1924/1925: 123. 
and intellectual activity. ${ }^{26}$ "Natural selection" (Bogdanov places the term in inverted commas), did not always operate in isolation: for many thousands of years before "natural selection" had been discovered, it had been assisted in human societies by the practice of artificial selection. ${ }^{27}$

"As concerns the adjective 'natural', we shall discard it, for in tektology the difference between 'natural' and 'artificial' processes is not important. ... All production, all social struggle, all the work of thinking, proceeds constantly and steadfastly by means of selection (podbor): by systematic support of the complexes corresponding to vital human goals, and the elimination of those that contradict them." 28

How then, during the transition period, would "the work of thinking" obtain "systematic support"? Bogdanov's answer was that it would be provided by educational institutions that functioned alongside the state educational system, namely the Proletarian Workers' Cultural-Educational Organization (Proletkul't) and the Proletarian University. The function of these institutions would differ from that of traditional pedagogy in which "the entire meaning of the educator's activities [was] to support and strengthen some elements of a child's psyché and to destroy or inhibit others".29 A "collectivist education" would develop in the psyché of the individual a "discipline of comradely relations" and a "conscious acceptance of common interests and aims." ${ }^{\text {"30 }}$

Bogdanov's conception of the social function of the arts and of art criticism is analogous to his conception of the function of the new education. Art criticism, he tells us, should not be prescriptive, but this did not meant that the critic should be a mere reporter: the critic should "monitor (reguliruet) the development of art", and give warning whenever "young art" succumbed to "alien influences".31 What criteria did Bogdanov wish to be applied in the course of "tektological selection"? Did he think that "regulation" would be carried out by proletarians themselves, or by others on their behalf?

\section{Culture as mentalité?}

\section{i) The social origins of the artist}

In 1910 Bogdanov had written: "The proletariat needs its own, socialist art, permeated by its own feelings, aspirations and ideals." "32 In 1918 he wrote that, ideally, what the proletariat needed was a "pure-class, proletarian poetry".33 In 1920, he dismissed the Belgian, Emile Verhaeren, and the Latvian, Jānis Rainis, ${ }^{34}$ as "poets of the toiling democracy", as "socialist intellectuals", who were "bound to the working class by a common ideal, but who, having been brought up in another world, cannot directly express or organize proletarian artistic consciousness." ${ }^{\prime 35}$ Such statements seem to imply an understanding of working class culture as mentalité, as a function of social origins and social milieu. However, as we shall see, for Bogdanov working class origins or experience were necessary, but not sufficient conditions for the production of proletarian culture. Proletarian culture was also a matter of values, of "world view" that required carefully nurtured.

\footnotetext{
26 For the explanation in Tektology of "selection" (podbor) as a "tektological" process, see Bogdanov 1996, Chapter 3: Basic Organizational Mechanisms. I have here also used Bogdanov, 1922. On this subject, see Poustilnik 2009, especially 125-129.

27 Bogdanov 1996, Chapter 3: Basic Organizational Mechanisms, 179.

28 Bogdanov 1996, Chapter 3: Basic Organizational Mechanisms, 175.

29 Bogdanov 1996, Chapter 3: Basic Organizational Mechanisms, 181-182.

30 "Ideal vospitaniya" (Lecture delivered to a Teachers' Conference in Moscow, May, 1918), in Bogdanov 1924/1925: 236.

31 Bogdanov 1911:87

32 "Sotsializm v nastoyashchem" (1910), in Bogdanov 1924/1925: 98.

33 "Chto takoe proletarskaya poeziya?" (1918), in Bogdanov 1924/1925: 131.

34 The work of Rainis had appeared in 1916 in Sbornik Latyshskoy literatury (An Anthology of Latvian Literature), edited by Valeriy Bryusov and Maksim Gorkiy.

35 "Prostota ili utonchennost'?" (1920), in Bogdanov 1924/1925: 178-179.
} 


\section{ii) The world view of the critic}

The importance that Bogdanov attached to "world view" enabled him to introduce the critic, pedagogue, or ideologue, into his tektological understanding of cultural evolution. In 1923, he explained how someone who had not been born into, or did not otherwise belong to a working class milieu, could contribute to the development of proletarian culture:

"... The position of a class in the system of social life is an objective fact, and it creates the possibility for an ideologue, even one who does not belong to that class, to adopt its position theoretically [my emphasis-jb] and from that position to obtain a new point of view. This is what Marx succeeded in doing."36

This notion of an historically appropriate world view being a kind of accreditation that entitled an individual to participate in the construction of proletarian culture, enabled Bogdanov to rationalize his own role as a critic of culture, and to offer his General Organizational Science (Tektology) as a key to the understanding of, and as an integral part of, the emerging ideology of collectivism. By the same logic he would recommend that the first tutors of the Proletarian University should be drawn from "the most able theorists of revolutionary socialism" and, subsequently, from amongst graduates of the Socialist Academy. ${ }^{37}$

\section{Building collectivist values}

Bogdanov's assessment of the value of a work of art was based upon the extent to which it succeeded in its cognitive and educational functions, which he described as its "organizational task".38 This task was, "firstly, to organize a particular sum of the elements of life, of experience (opyt); and, secondly, to ensure that what is created serves as an instrument for a particular collective." ${ }^{\prime 39}$ With this dual conception of the role of the artist and critic in mind, Bogdanov devised what one might describe as a 'utilitarian aesthetics', the purpose of which was to foster the development of collectivism within the proletariat. His aesthetics addressed the issues of both content and form. His declared criteria of judgment were: a) how far and in what respects the "material" of a work of art was of value to the proletariat and to the all-human (obshchechelovecheskiy) collective of the future; b) how far the "methods" applied were useful and appropriate (prigodny); and c) the general significance for the higher collective of the resolution of a specific organizational task. ${ }^{40}$ In the building of collectivist norms or values, these criteria were to be applied in selecting from the cultures of the past, and in evaluating artistic works of the present day.

\section{i) Content: selecting from the culture of the past}

In an editorial published in the first issue of the journal of the Proletkult, Proletarskaya kul'tura, Bogdanov argued against any radical break with the culture of the past: "The proletariat is the legitimate heir of all the valuable achievements of the past, spiritual as much as material; it cannot and must not repudiate this legacy."41 In the third issue of the journal he deplored the "Hindenburgian" tone adopted by Vladimir Kirillov, who had proclaimed that "In the name of our tomorrow we shall burn

36 "Ot monizma religioznogo k nauchnomu", in Bogdanov 1923: 342.

37 "Proletarskiy Universitet" (1918), in Bogdanov 1924/1925: 252. See also Steinberg 2002: 60.

38 Cf. Chehonadskih 2018: 4 - "Art is one of the many forces within the ontology of organization."

39 "O khudozhestvennom nasledstve" (1918), in Bogdanov 1924/1925: 150.

40 See especially Thesis No.4 of "Tezisy doklada A.A.Bogdanov. 'O proletarskoy kritike'. na Vserossyiskom soveshchanii literaturnykh otdelov i otdelov izobrazitel'nykh iskusstv proletarskikh kul'turno-prospevetitel'nykh organizatsii, 21 August 1921. RGALI, f.1230, op.1, d.457, I.8. I am obliged to Petr Plyutto for making this document available.

41 "1918" in Bogdanov 1924/1925: 102. This had originally been published in Proletarskaya kul'tura, Nr.1 (July 1918).under the title 'From the editorial board', ('Ot redaktsii"). 
Raphael, destroy the museums, trample upon the flowers of art".42 The culture of the past should not be embraced uncritically: the correct approach was to seek out the "hidden elements of collectivism".43

\section{ii) Content: selecting from the culture of the present}

The construction of collectivism also required an ability to detect values that were not progressive. This required an understanding of the fact that art both organized the social class to which an artist belonged, and interpreted the world from the point of view of that social class. "Behind the individual author is hidden the collective author, the author's class; and poetry is part of the self-awareness of this class." In the nineteenth century, the poetry of Afanasiy Fet had expressed the world- view of the Russian nobility; ${ }^{44}$ and Nikolay Nekrasov, who had spoken up for the exploited peasantry, had at the same time articulated the aspirations, ideas and sentiments of the urban intelligentsia to which he belonged by occupation, and of the landlord estate to which he belonged by birth. ${ }^{45}$ Indeed, the greater part of what, more recently, purported to be "democratic" poetry in fact gave expression to a "peasant-intellectual", "worker-peasant" or "worker-peasant-intellectual" view of the world. ${ }^{46}$

\section{Progressive forms}

\section{i) "Simplicity" (prostota)}

How, Bogdanov asked, was one to identify those writers of the past who could serve as models for the kinds of techniques to be adopted by the creators of proletarian culture? In answering this question he drew upon his evolutionary interpretation of history and upon his organization theory. Every social formation and every ideology, he argued, went through a life-cycle of birth, maturation, degeneration (vyrozhdenie) and death. This could be observed not only in the content but also in the forms of art. ${ }^{47}$ It was during the phase of growth and maturity that the art of a civilization attained its most consummate expression. Proletarian writers should therefore "learn the techniques of art ... from the great masters who emerged during the rise and flowering of those classes that are now withering away - the revolutionary romantics and the classics of different times." 48 The hallmark of art at its apogée was its "simplicity".49 In 1918, Bogdanov lauded the "simplicity, clarity and purity of forms" of Pushkin, Lermontov, Gogol, Nekrasov and Tolstoy. ${ }^{50}$ In 1920 (when he added Byron to this list), he wrote:

"What we find in the work of the great masters is a simplicity that is associated with content that is grandiose, developing or highly developed, but which has not yet begun to degenerate. Goethe and Schiller, and in Russia, Pushkin and Lermontov, reflected the birth and growth of new conditions and new forces of life, the rise of a bourgeois culture that was beginning to oust and supplant the old, feudal-aristocratic culture." ${ }^{\prime \prime 1}$

\footnotetext{
42 "Kritika proletarskogo iskusstva" (1918), in Bogdanov 1924/1925: 173.

43 See "O khudozhestvennom nasledstve" (1918), in Bogdanov 1924/1925: especially, 142-145; and Thesis Nr. 16 of "Puti proletarskogo tvorchestva" (1920) in Bogdanov 1924/1925: 199.

44 Afanasiy Afanas'evich Fet (1820-1892). See "Chto takoe proletarskaya poeziya?" (1918) in Bogdanov 1924/1925: 130. See also the section "Tekhnicheskie i ekonomicheskie osnovy kollektivizma" in Nauka ob obshestvennom soznanii (1914) in Bogdanov 1999: 452.

45 Nikolay Alekseevich Nekrasov (1821-1878). See "Chto takoe proletarskaya poeziya?" (1918), in Bogdanov 1924/1925: 131.

46 As an example, Bogdanov cites a poem by Alexei Gmyrev, Alaya. See "Chto takoe proletarskaya poeziya?" (1918), in Bogdanov, 1924/1925: 132-133. See also the references to Emile Verhaeren and Jānis Rainis, above.

47 "Kritika proletarskogo iskusstva" (1918), in Bogdanov 1924/1925: 169

48 "Kritika proletarskogo iskusstva" (1918) in Bogdanov 1924/1925: 170.

49 Cf. "Like most ancient Martian works of art, the most modern works were characterized by extreme simplicity and thematic unity". Bogdanov 1984: 76

50 "Kritika proletarskogo iskusstva" (1918), in Bogdanov 1924/1925: 170

51 "Prostota ili utonchennost'?" (1920), in Bogdanov 1924/1925: 176-177.
} 


\section{ii) Rhyme and Rhythm}

In his understanding of rhythm (ritm) and rhyme (rifma) Bogdanov updated romanticism for the machine age: these two devices served to integrate the human community in its relationship with the rest of nature, and also in work and thought: Asked by Leonid, in Red Star, whether "the poetry of the socialist epoch should abandon and forget these inhibiting rules", Enno replies:

"Regular rhythm (pravil'noe-ritmicheskoe) seems beautiful to us not because of any adherence to convention, but because it is in profound harmony with the rhythmic regularity of the processes of our life and consciousness. As for rhyme, whereby a series of variations end in a single accord, does it not have a profound kinship with that vital bond between people that enables them to overcome their inherent diversity and achieve unity in the pleasure of love, and from having a rational objective in work ...? There can be no artistic form without rhythm (bez ritma). If there is no rhythm of sounds it is all the more essential that there should be a rhythm of images or ideas. And whilst rhyme (rifma) is really of feudal origin, so were many other good and beautiful things."52

\section{Degenerate form and content: "preciosity" (utonchennost')}

True to his biological-evolutionary world view, Bogdanov was disparaging of the forms and content of art produced at the end of the life-cycle of a social formation. In 1908, in Red Star he had written:

"[The art of] intermediate, transitional, epochs is of quite a different character: there are impulses, passions, restless yearnings that are sometimes suppressed in the divagations of erotic or religious dreams, but which at other times erupt when tensions in the conflict between body and soul reach the point of disequilibrium."53

Ten years later, he explained more fully:

"... When a social class has accomplished its progressive role in the historical process and begins to decline, the content of its art, inevitably, also becomes decadent, as do, accordingly, the forms of art that adapt to this content. The decay of a ruling class is usually evident in a descent into parasitism. There is an onset of satiety, a dulling of the sense of life. Life loses its main source for new, developing content - socially creative activity. In order to fill this void, the members of the dying class pursue ever new pleasures and sensations. Art organizes this quest: in an attempt to stimulate fading sensibilities it resorts to decadent perversions; in an attempt to elaborate and refine aesthetic images, it complicates and embellishes artistic forms through a mass of petty contrivances. All of this has been observed in history more than once, in the decline of various cultures - the Oriental, Classical and Feudal, and it can be observed during recent decades in the decay (razlozhenie) of bourgeois culture, in most of the new trends in 'Modernism' and 'Futurism'. Russian bourgeois art has dragged itself along in the wake of European art, in the image of our anemic and flabby bourgeoisie which succeeded in withering without ever having bloomed."54

Zinaida Gippius was considered by Bogdanov to be typical of those who "in periods of tranquil reaction contemplate their individual feelings, aesthetic, erotic, mystical ... who become fiery patriots in wartime and who are seized by the ardor of struggle during revolution, only to lapse back into eroticism and all sorts of perversions, mysticism theosophy, etc., etc., when the forces of reaction become dominant.".55 [Leonid] Andreev, [Konstantin] Bal'mont and [Alexandr] Blok were "on our side one moment and detached the next".56 The work of [Valeriy] Bryusov and [Andrey] Belyy was "devoid of

\footnotetext{
52 My translation from Krasnaya Zvezda, Bogdanov 1929: 97, with reference to the translation by Charles Rougle in Bogdanov $1984: 78$.

53 My translation from Krasnaya Zvezda, Bogdanov 1929: 94, with reference to the translation by Charles Rougle in Bogdanov $1984: 76$.

54 "Kritika proletarskogo iskusstva" (1918) in Bogdanov 1924/1925: 169-170.

55 "Prostota ili utonchennost'?" (1920), in Bogdanov 1924/1925: 178-179. See also 175-177.

56 "Kritika proletarskogo iskusstva" (1918), in Bogdanov 1924/1925: 170.
} 
living content and devoted entirely to form",; [Vladimir] Mayakovskiy was "a posturing, self-advertising intellectual" (krivlyayushegosya intelligenta-reklamista); [lgor] Severyanin was "the ideologue of gigolos and women of easy virtue (al'fonsov $i$ kokotok) and the talented embodiment of painted vulgarity."58

There was a risk that the art of the proletariat would be contaminated by the Modernists' experimentation with rhyme and rhythm:

"In its first steps our workers' poetry manifested a tendency to regular rhythmic verse with simple rhymes. At present, it manifests a tendency to free rhythms (svobodnye ritmy) and complex, interweaving, novel and often unexpected rhymes. This is clearly the influence of the poetry of the new intelligentsia. It is hardly to be welcomed." 59

By contrast, the science of "physiological psychology" had shown how actions and resistances in work had a formative influence upon the nervous system. It was therefore desirable that the rhythms of poetry should correspond to the "directing rhythms" experienced by a worker who was in harmony with the machine, and to the rhythms of nature. ${ }^{60}$ Above all, there should be no striving for effect. ${ }^{61}$

Conscious, perhaps, that his views on culture might be considered overly conservative, Bogdanov was, on occasion, prepared to concede that "of course, new content will inevitably give rise to new forms"; the main thing was "to take the best of the past as a starting point."62 However, he was profoundly out of sympathy with Modernism. In 1920 he felt entitled to remonstrate with Gerasimov (who, unlike Bogdanov, was of working class origin), ${ }^{63}$ for having succumbed, in Mona Lisa, to the influence of the modern poets. ${ }^{64} \mathrm{He}$ admonished as "naïve" the Smithy (Kuznitsa) group of writers (Gerasimov and Vladimir Kirillov were founder-members), who, in the first issue of their journal had declared that, even if they were unable to write "proletarian poetry" (a barb directed at the Proletkult), they would dedicate themselves to developing a mastery of literary techniques. ${ }^{65}$ These writers, Bogdanov chided, should not "deck themselves out in the finery of the bourgeoisie", but seek the content of their poetry in comradely relations, in the experience of workers' organizations and in the works of Marx. They should trust in the collective and in its evolutionary ideology, and amongst past writers seek out those who had "shown the way".66

57 "Prostota ili utonchennost'?" (1920), in Bogdanov 1924/1925: 180. Here Bogdanov is criticizing Mikhail Gerasimov's poem Mona Lisa.

58 "Kritika proletarskogo iskusstva" (1918), in Bogdanov 1924/1925: 170. Bogdanov did not deny the talent of either Severyanin or Mayakovskiy. See his footnote on Mayakovskiy, dated 1924, in this same article: 170. Ironically, Lenin, shared Bogdanov's antipathy for the Futurists: on 6 May 1921 Lenin rebuked Lunacharskiy for printing 5,000 copies of Mayakovskiy's 150,000,000 and implored M.N. Pokrovskiy to help him "fight Futurism". See Lenin to A.V. Lunacharskiy, 6 May 1921 and Lenin to M.N. Pokrovskiy, 6 May 1921, in Lenin 1970, 179-180.

59 "Kritika proletarskogo iskusstva" (1918), in Bogdanov 1924/1925: 170-171.

60 "Powerful machines and their precise movements are aesthetically pleasing to us in and of themselves...." Enno, in Bogdanov $1984,74$.

61 "Prostota ili utonchennost'?" (1920), Bogdanov 1924/1925: 188-9.

62 "Kritika proletarskogo iskusstva" (1918), Bogdanov 1924/1925: 170

63 Mikhail Prokof'evich Gerasimov (1889-1939), the son of a railway worker, had himself worked in the railway, metal working and mining industries. Between 1910 and 1914 he was a member, alongside Lunacharskiy, A.K. Gastev and F.I. Kalinin of the Paris-based Liga proletarskoy kul'tury. His works were published in Gorkiy's Prosveshchenie in 1913 and 1914; in an anthology edited by II'ya Erenburg - Vechera (Paris, 1914); in Sbornik proletarskikh pisateley (1914) which had a foreword by Gorkiy; and in Sbornik proletarskikh poetov (1917). In 1917 a volume of his poetry, due to be published by Gorkiy's publishing house Parus, was banned by the censor. In March 1917 he was elected chair of the Samara Soviet of Soldiers'Deputies and from 1918 he was chair of the Samara Proletkult. See Russkie pisateli 1989: 540-541.

64 "Prostota ili utonchennost'?" (1920), in Bogdanov 1924/1925: 180.

65 Mikhail Gerasimov and Vladimir Kirillov were prominent in the Kuznitsa group who held their founding meeting in February 1920. See Brown 1971: 10-12.

66 "Prostota ili utonchennost'?", (1920), in Bogdanov 1924/1925: 190-191. This article was published in Proletarskaya kul'tura (1920), Nr.13-14. See also Bogdanov's review of the first issue (May, 1920) of the journal Kuznitsa, in Proletarskaya kul'tura (1920), Nr.15-16: 91-92. 


\section{Organizational aesthetics}

Another framework that Bogdanov applied in evaluating a work of art, namely its 'degree of organization' or 'organized-ness (stepen' organizovannosti), ${ }^{67}$ derived directly from his Tektology and seems to supplement, if not replace, his binary opposition of 'simplicity/over-elaboration'. In Part III of the full version of Tektology (first published in 1922), in the chapter 'Organizational Dialectics', he wrote:

"All of the usual human evaluations that take the form of such concepts as goodness, beauty and truth, that is, moral, aesthetic and cognitive evaluations, have one common basis: all of them are organizational evaluations. The fetishized forms of these evaluations, which conceal their true nature from individualistic consciousness, prevent the question of the degree to which they represent socially-experienced levels of organization (sotsial'no-zhiznennoi organizovannosti) from being addressed. This means that whatever raises the level of organization of collective life in the field of degressive norms of human behaviour is deemed to be morally superior; ${ }^{68}$ whatever has this effect in perceptions of the world (mirovospriyatyia) is deemed to be beautiful; and whatever has this effect when it comes to the systematization of experience is deemed to be 'true.' At the present time, all such evaluations amounted to a more or less crude, approximate, and vaguely defined quantitative measure of the degree of organization, in other words, to a "measurement" according to some imprecise scale or template. For this reason, they needed to be subjected to scientific research. In due course they would be replaced by scientific-organizational evaluations."69

In the same year, addressing a conference of writers and artists of the Proletkult, Bogdanov made the same point, namely that appreciation of the formal side of a work of art consisted in evaluating the "degree to which that work was organized as a living whole". Acknowledging that assessments made by different collectives would vary according to their specific accumulations of organizational experience, he argued that, nevertheless, "it is the degree of organization of a work that is the measure of its profundity and of the impact that it will have upon the collective, that is, of its potential for contributing to the organizational education of the collective."70 The extent to which a work of art achieved a degree of organization also determined its aesthetic effect, for "truth is the presence of organization in the sphere of experience; the good is the presence of organization in the sphere of action; and beauty is the presence of organization in the sphere of the emotions."111

\section{A tektological criticism of Hamlet}

Disappointingly, there is only one instance (that I can think of) in which Bogdanov applies in any detail the methodology of organizational science to the exegesis of a work of art or literature, and that is in his commentary on "the great artist and tektologist", Shakespeare. ${ }^{72}$ The divided self of Hamlet, he tells us (divided, on the one hand by his warrior upbringing and, on the other, by his passive-aesthetic temperament), formed a "complex", the components of which were in a relationship of "disingression",

67 George Gorelik translated organizovannost' as 'system-ness.' See Gorelik 1984: 279. Bogdanov does use the term sistematizatsiya, so another possible translation might be 'degree of systematization'.

68 "Degression", for Bogdanov, is the process that enables a particular form to sustain its structure or viability in a relationship of dynamic equilibrium with its environment. See Bogdanov 1922: Part II, Chapter VI, Section 3 - 'Origin and significance of degression'.

69 My translation from Bogdanov 1922: 516.

70 See Thesis Nr. 4 for his lecture "On proletarian literary criticism" delivered to an All-Russian Conference of Literary Departments and Departments of the Visual Arts of the Proletkult, 21 August 1921. RGALI, f.1230, op.1, d.457, I.8.

71 Bogdanov, Unpublished notebooks, RGASPI, f.259, cited by: Iu.P. Sharapov, "'Kul'turnye lyudi soznatel'no uchityvayut proshloe". Iz zapisnykh knizhek A.A. Bogdanova", Istoricheskiy arkhiv (1999), Nr. 3: 174.

72 The expression is employed in Bogdanov 1922, Part II, Chapter 5 "Divergence and convergence of forms", Section 6: "The division and restoration of unity of the personality", p.292. Part II of Tektology was first published in Moscow in 1917 (Preface dated 22 September 1916). Bogdanov also provides a commentary on Hamlet in "O khudozhestvennom nasledstve" (1918), in Bogdanov 1924/1925: 150-154. 
or paralysis. The processes of selection set in motion by a hostile environment could only result in the destruction of this complex (as in the "insanity", then death, of Hamlet), or in a recombination of the elements of his psyché into a new "active-aesthetic" whole (the restoration of order, or "system equilibrium", in the character of Fortinbras). ${ }^{73}$ Hamlet, was an example of how a work of art could serve not only the dominant ideology of its time, but also the evolution of collectivism, in that Shakespeare's depiction of the struggle for harmony in a hostile environment, "provides the working class with a comprehensive lesson and a comprehensive resolution of the organizational task - and that is what is needed if the world- organizational ideal is to be achieved." 74

\section{Between learning and didacticism}

Bogdanov was at pains to insist that no constraints should be placed upon the creative work of the proletarian artist: there should be "initiative, criticism, originality and the all-round development of individual talents."There should be no "blind submission to authority".75 He did not think that his own exercises in literary and artistic criticism were prescriptive; but it is difficult to avoid the conclusion that, sometimes, they were. In 1918, it is true, he rejected the civic (grazhdanskoe) notion according to which art should explicitly propagate particular values: there was "no need to attach any aims to art they are an unnecessary and harmful constraint.". At the same time, he was himself of the opinion that proletarian art should express an "aspiration towards the ideal" and pointed to the example of the Venus de Milo which, he maintained, represented the harmonious unity of spiritual and physical love; ${ }^{.77}$ and to Goethe's Faust which depicted the human soul in its search for harmony, eventually attained in a life devoted to working for the good of society. ${ }^{78}$ Conscious, perhaps, that such a critique could, indeed, be considered "civic", he dissociated himself from the theory "recently brought forward", according to which art must be "unflaggingly uplifting" (zhizneradostnoe) and "exultant" (vostorzhennoe). "We are sorry to say that this theory is quite fashionable, especially with the younger and less experienced proletarian poets, although it can only be called childish." ${ }^{179}$ Even so, in some of his writings, Bogdanov's didactic attitude is reminiscent of the philosopher of an earlier Enlightenment, Jean-Jacques Rousseau, in his Émile, ou De l'éducation (1762).

As early as the spring of 1919 Bogdanov had become aware that some proletarian writers found his approach patronizing:

"Some Proletkultists have argued that artistic creation must be free, and have questioned whether criticism, however scientific, and however much it claimed to be the most proletarian, can point the way ... the journal Proletarskaya kul'tura has been depicted as a kind of baby-sitter ("Chto za nyan'ki!'), constantly fretting about what is and what isn't proletarian culture".80

In February 1920, exasperation with the paternalism of the Proletkult led a group of writers led by Gerasimov to withdraw from its Moscow branch and, under the auspices of the Commissariat for

73 Bogdanov 1922, Part II, Chapter 5 "Divergence and convergence of forms", Section 6: "The division and restoration of unity of the personality": 290-292.

74 "O khudozhestvennom nasledstve" (1918), in Bogdanov 1924/1925: 154.

75 "Ideal vospitaniya" (Lecture delivered to a Teachers' Conference in Moscow, May, 1918), in Bogdanov 1924/1925: 236.

76 "Chto takoe proletarskaya poeziya" (1918), in Bogdanov 1924/1925: 128-129. See also Thesis Nr. 11: "The socio-organizational role of art is its objective meaning, and this interpretation has nothing in common with the theory of civic art, whereby art is harnessed to certain specific tasks of an ethical, political or other nature", in "Sotsial'no-organizatsionnoe znachenie iskusstva" (1921) in Bogdanov 2004: 5-9.

77 "Proletariat i iskusstvo" (Speech to the First All-Russian Conference of the Proletkult, 20 September 1918), in Bogdanov 1924/1925: 122-23.

78 "Proletariat i iskusstvo", (Speech to the First All-Russian Conference of the Proletkult, 20 September 1918), in Bogdanov 1924/1925: 120-121; and "Prostota ili utonchennost'?" (1920), in Bogdanov 1924/1925: 178.

79 "Kritika proletarskogo iskusstva" (1918), in Bogdanov 1924/1925: 167.

80 Bogdanov 1920: 87. On the resentment of some writers by 1920, see Steinberg 2002: 60-61. 
Education, to organize their own literary group - Kuznitsa, complaining that "the conditions of work in Proletkult ... for a variety of reasons, restrict the creative potential of proletarian writers." ${ }^{11}$ It was the Kuznitsa group that in October 1920 organized the First All Russian Congress of Proletarian Writers during which the All-Russian Association of Proletarian Writers (VAPP) was founded. ${ }^{82}$ In December 1920, the replacement of Pavel Lebedev-Polyanskiy by Valerian Pletnëv as Chair of the Central Committee of the Proletkult marked the beginning of the end of Bogdanov's influence inside the Proletkult. In November 1921 he resigned from all positions in the Proletkult in order to devote himself entirely to research in blood transfusion. However, the matter did not end there: the critics of Bogdanov, in some cases acting under the instructions of Lenin, now faced the task of producing an alternative to his theory. During the later 1920s, Pletnëv, for one, ostentatiously dissociated himself from Bogdanov and played his own ignoble part in the creation of a new orthodoxy. ${ }^{83}$ On 9 May 1924 the Press Department of the Central Committee of the Communist Party convened a conference on "The policy of the Party in artistic literature" and in 1925 published materials of this conference and other contributions to the debate. ${ }^{84}$ In the same year Bogdanov defiantly published an anthology of his own writings on the subject. ${ }^{85}$ He could legitimately take the view that his "heresies" (his own term) had set the agenda for the debate.

\section{Conclusion}

One does not look to Bogdanov for an understanding of the mentalité of the 'actually existing' working class. ${ }^{86} \mathrm{His}$ concern was not with working class communities but with the 'integral proletarian', the ideal-typical worker of the future. He would cite Nikifor Vilonov and Fëdor Kalinin, work-organizers of the Capri School as examples. ${ }^{87}$ In this respect he was a utopian socialist (I do not use the term pejoratively).

Bogdanov's insistence that a 'non-proletarian' could make a contribution to the development of proletarian culture clearly belongs to the vexed controversy over the ambiguous relationship between socialist intellectuals and workers by social origin. ${ }^{88} \mathrm{His}$ conviction that his self-identification as a Collectivist qualified him for the role of builder of socialist culture is questionable. Perhaps he is better understood as a member of the 'normative intelligentsia', whose ascendancy he would himself later describe. ${ }^{89}$

Bogdanov's aesthetic theories had the potential for development in a number of directions, but some led up blind alleys. His binary criterion of'simplicity/over- elaboration'seems to have owed more to his solicitude for novices in the building of proletarian culture and to his dislike of Modernism than to his organization theory. It is difficult to imagine what contribution these categories could make to the appreciation of even some of the writers he approved of, for example, Gogol. By contrast, his

81 See their letter to Pravda, 5 February 1920, reproduced in Gorbunov 1974: 122. On this episode, ssee also Mally 1990: 154-156.

82 It was also in October 1920 that Lenin took steps to have the Proletkult subordinated to the Commissariat for Education. These institutional changes in the history of the movement for proletarian culture have been well documented by Sheshukov 1970, Brown 1971 and Eimermacher 1972.

83 On the role of Pletnëv in the debate over cultural policy, see Mally 1990. Chapter 7.

84 See Voprosy kul'tury pri diktature proletariata 1925. Moscow \& Leningrad: Gosizdat, On this debate, see also Biggart 1992.

85 See O proletarskoy kul'ture 1904-1924. This inside title page of this anthology is dated 1924 and the cover is dated 1925.

86 In general, it seems that the Russian Social Democrats, before 1917, produced fewer social and economic studies of working class life than the agrarian socialists did of the peasantry.

87 On Kalinin, see "Novy tip rabotnika" in Bogdanov 1920. Bogdanov quotes from an unpublished work by Vilonov in his Introduction and in Chapter 6 of Filosofiya zhivogo opyta 1913 and 1923. See also Scherrer 1980: 165-187; and, on Vilonov and Kalinin, Gloveli 2004, 25-48.

88 See Biggart 1990: 265-282. On how workers and intellectuals worked together in the Proletkult, see Mally 1990: $115-121$.

89 See "Linii kul'tury XIX i XX veka" in Bogdanov 1995; in Vestnik Mezhdunarodnogo Instituta Bogdanova 2000 (4): 28-53; and Gloveli 2009, 47-79. Archival research suggests that this work was written in November 1924. 
criticism of Hamlet illustrates the analytical potential of a tektological approach. In mitigation we can say that Bogdanov was aware of the experimental nature of his aesthetics. He was aware that a scientific-organizational aesthetics would be perfected only in the future. .90

\section{Commentary by Chris Read}

The deepest distinguishing aspect of Bogdanov's ideas is his relentless pursuit of the implications of an uncompromising materialist interpretation of life and thought. By his standards, even as militant a materialist as Lenin was infected with remnants of idealism. Perhaps the most speculative and crucial issue in the materialist/idealist debate is the question of the relationship of matter and thought, the intersection of brain cells and consciousness. This issue, despite claims to the contrary, is far from being resolved. Art and culture are pre-eminent products of consciousness. How illuminating, or so it should be, to have a careful presentation of Bogdanov's approach to Shakespeare's Hamlet. What does it illuminate? In many respects it shows the limitations of Bogdanov's ideas as much as their valuable pioneering elements. John Biggart expertly - and we have no more trustworthy guide than he on this - dissects Bogdanov's interpretation. Broadly, as Biggart shows, Bogdanov saw the class content of a cultural/artistic product as its most important aspect from the proletarian perspective. Today, the notion of cultural output embodying social values surprises no one. As a pioneer, Bogdanov was fighting against a more sceptical audience but also using analytical tools that look reductive and oversimplified today. Hamlet, as provider of'a comprehensive lesson and comprehensive resolution of the organisational task', is a very particular, idiosyncratic, and limited interpretation. At the same time, Bogdanov's approach is stimulating and inspiring. His achievement may lie mainly in his identification of key issues of the formation and importance of proletarian class consciousness. His suggestions for institutions that aim to incubate that consciousness - not just Proletkult but the Proletarian Encyclopaedia and the Proletarian University, foreshadowed embryonically in the Capri Party Schools - are ingenious suggestions set aside by later socialists at their peril. Bogdanov was better at identifying questions and suggesting mechanisms to deal with them than he was at providing solutions.

This consideration applies to another aspect of Bogdanov's achievement that looms large in Biggart's unblinking presentation. Bogdanov insisted on no feature of proletarian cultural formation more than that it should be the unhindered activity of the workers themselves. However, like Lenin in this respect despite their bitter differences, Bogdanov was endlessly prodding the creators in the direction he believed they must go. For someone who so prizes not being prescriptive, Bogdanov is ever ready to propose (impose?) his own judgments. He knows that proletarian class consciousness must be based on collectivism, but this pre-empts the free process. His ruthless exclusion of'part-proletarians' and writers of working-class origin who did not agree with him, and his strictures against (and sometimes, in favour) of 'great' artists and thinkers, seem more characteristic of a dogmatist than a liberator. The echo of his comments about Gippius lapsing 'back into eroticism and all sorts of perversions' and Severyanin as 'an ideologue of gigolos and women of easy virtue' makes one fear what he might have made of today's sexual identity and LGBTQ+ issues. Did Bogdanov share the 'stalinist' assumption that the working class was not queer? 


\section{References}

Biggart, J. 1990. Alexander Bogdanov and the theory of a "New Class". Russian Review (49, July): 265-282.

Biggart, J. 1992. Bukharin's theory of cultural revolution. The ideas of Nikolai Bukharin, edited by Anthony Kemp-Welch, 131-158. Oxford: The Clarendon Press.

Biggart, J.; Gloveli, G. and Yassour, A. 1998. Bogdanov and his Work. A guide to the published and unpublished works of Alexander A. Bogdanov (Malinovsky 1973-1928). Aldershot, Brookfield USA, Singapore, Sydney: Ashgate.

Biggart, J. 2021. 'The rehabilitation of Bogdanov'. https://jbiggart.academia.edu/research.

Bogdanov, A. 1901 Poznanie sistoricheskoi tochki zreniya. St. Petersburg: Tipografiya A.Leiferta.

Bogdanov, A. 1904. Iz psikhologii obshchestva. St. Petersburg: Izdanie S.Dorovatovskogo i A. Charushnikova.

Bogdanov, A. 1904-1906. Empiriomonizm. Stat'i po filosofii, I-III. Moscow \& St.Petersburg: Izdanie S.Dorovatovskogo i A.Charushnikova.

Bogdanov, A. 1906. Kratkii kurs ekonomicheskoi nauki. $7^{\text {th }}$ augmented edition. Moscow: Izdanie S. Dorovatovskogo i A.Charushnikova.

Bogdanov, A. 1908. Krasnaya zvezda (Utopiya). Saint-Petersburg: Tovarishchestvo khudozhnikov pechati

Bogdanov, A. 1911. Kul'turnye zadachi nashego vremeni. Moscow: Izdanie S.Dorovatovskogo i A. Charushnikova.

Bogdanov, A. 1913a. Vseobshchaya organizatsionnaya nauka: Tektologiya I. St.Petersburg: Izdanie Ml. Semenova.

Bogdanov, A. A. 1913b. Filosofiya zhivogo opyta. Populyarnye ocherki. Materializm, Empiriokrititsizm, Dialekticheskiy Materializm, Empiriomonizm, Nauka Budushchego. St. Petersburg: Izdanie MI. Semenova; 3rd ed., 1923. Petrograd-Moscow: Kniga; Translated, edited and introduced by David. G. Rowley as: The philosophy of Living Experience. Popular Outlines. 2006. Boston and Leiden: Brill.

Bogdanov, A. 1914. Nauka ob obshestvennom soznanii. Kratkii kurs ideologicheskoy nauki v voprosakh i otvetakh. Moscow: Knigoizdatel'stvo pisateley v Moskve.

Bogdanov, A. 1920a. "Novyy tip rabotnika", in Sbornik pamyati F.l.Kalinina. Rostov on Don: Gosizdat.

Bogdanov, A. 1920b. Elementy proletarskoy kul'tury v razvitii rabochego klassa. Lektsii prochitannyev Moskovskom Proletkul'te vesnoyu 1919 goda. Moscow: Gosizdat.

Bogdanov, A. 1921 "Sotsial'no-organizatsionnoe znachenie iskusstva" - Theses for a lecture delivered to the Russian Academy of Artistic Sciences, 29 October 1921, with an introduction by Charlotte Douglas, Vestnik Mezhdunarodnogo Instituta A. Bogdanova. 2004 (1): 17, 5-9.

Bogdanov, A. 1922. Tektologiya. Vseobshchaya organizatsionnaya nauka. Petersburg, Moscow, Berlin: Grzhebin.

Bogdanov, A. 1923. "Obshchestvenno-nauchnoe znachenie noveishikh tendentsii estestvoznaniya" (Theses for lecture delivered in the Socialist Academy of Social Sciences, 24 May 1923). Arkhiv RAN, f.350 op.2, d.4, II.13-78.

Bogdanov, A. 1925. O proletarskoy kul'ture 1904-1924. Leningrad-Moscow: Kniga.

Bogdanov, A. 1929. Krasnaya Zvezda. Leningrad: Krasnaya gazeta [Reprinted in Krasnaya zvezda: roman-utopiya; Inzhener Menni: fantasticheskiy roman. 1979. Bibliotheca russica. Hamburg: Helmut Buske Verlag].

Bogdanov, A. 1984. Essays in Tektology. The General Science of Organization. 2nd ed. Edited and translated by George Gorelik. Seaside California: Intersystems Publications Limited. 
Bogdanov, A. 1984. Red Star. The First Bolshevik Utopia. Edited by Loren R.Graham and Richard Stites, translated by Charles Rougle. Bloomington, Indianapolis: Indiana University Press.

Bogdanov, A. 1995. Stat'i, doklady, pis'ma i vospominaniya 1901-1928, in Neizvestnyy Bogdanov, Kniga 1, edited by NS. Antonova \& NV. Drozdova. Moscow: ITs AIRO - XX

Bogdanov, A. 1996. Bogdanov's Tektology, Book 1. Edited and translated by Peter Dudley, Vadim N. Sadovsky and Vladimir V. Kelle. University of Hull: Centre for Systems Studies.

Bogdanov, A. 1999. Poznanie sistoricheskoy tochki zreniya. Izbrannye psikhologicheskie trudy. Moscow: Moskovskiy psikhologo-sotsial'nyy institut.

Bogdanov, A. 2003. Tektologiya. Vseobshchaya organizatsionnaya nauka. Moscow: Finansy.

Bogdanov, A. 2000. "Sotsial'no-organizatsionnoe znachenie iskusstva" - Theses for a lecture delivered by Alexander Bogdanov to the Russian Academy of Artistic Sciences, 29 October 1921", with an introduction by Charlotte Douglas in Vestnik Mezhdunarodnogo Instituta A. Bogdanova (1): 17, 5-9.

Bogdanov, A. 2020. Empiriomonism. Essays in Philosophy, Books 1-3. Edited and translated by David G. Rowley. Boston and Leiden: Brill.

Brandist, C. 2015. The Dimensions of Hegemony. Language, Culture and Politics in Revolutionary $R$ ussia. Boston and Leiden: Brill.

Brown, EJ. 1971. The proletarian episode in Russian literature, 1928-1932. New York: Octagon Books.

Chehonadskih, M. 2018. The Stofflikhkeit of the Universe: Alexander Bogdanov and the Soviet Avant-Garde. e-flux journal \# 28-february. 1-9.

Eimermacher, K. 1972. Dokumente zur sowjetischen Literaturpolitik 1917-1932. Stuttgart:

W. Kohlhammer.

Feuer, LS. [Editor] 1959. Marx and Engels. Basic Writings on Politics and Philosophy. New York: Doubleday Anchor.

Gloveli, GD. 2004. Raduga dum i chuvstv' i 'krasochnaya shkola. Vestnik Mezhdunarodnogo Instituta A.Bogdanova Moscow, 18, 25-48.

Gloveli, GD. 2009. The sociology of Alexander Bogdanov and the theories of progress in the $19^{\text {th }}$ and early $20^{\text {th }}$ centuries" in Oittinen, Vesa (Ed.), Aleksandr Bogdanov Revisited Helsinki: Aleksanteri Series, 1, 47-79.

Gorbunov, VV. 1974. Lenin i Proletkul't. Moscow: Izdatel'stvo politicheskoy literatury.

Grille, D. 1966. Lenins Rivale. Bogdanov und seine Philosophie. Cologne: Verlag Wissenschaft und Politik.

Lenin, VI. 1970. Polnoe sobranie sochineniy, 52. Moscow: Izdatel'stvo politicheskoy literatury.

Lenin, VI. 1967. V.I. Lenin o literature i iskusstve. $3^{\text {rd }}$ edition, augmented. Moscow: Khudozhestvennaya literatura.

Mally, L. 1990. Culture of the Future. The Proletkult Movement in Revolutionary Russia. Berkeley, Los Angeles, Oxford: University of California Press.

Marx, K. and Engels, F. 2001. Collected Works, 49. London: Lawrence and Wishart.

Marx, K. and Engels, F. 1976. K. Marks i F. Engels. Ob iskusstve. 2 volumes, edited by M. Lifshits. Moscow: "Iskusstvo".

Poustilnik, S. 2009. Tectology in the context of intellectual thought in Russia. Vesa Oittinen, Editor, Aleksandr Bogdanov Revisited. Helsinki: Aleksanteri Series, 1.

Rose, MA. 1994. Marx's lost aesthetic. Cambridge: Cambridge University Press.

Russkie pisateli 1800-1917. Biograficheskiy slovar', I 1989. Moscow: Izdatel'stvo "Moskovskaya Entsiklopediya".

Sbornik Latyshskoi literatury. 1916. Edited by Valeriy Bryusov and Maksim Gor'kiy, with a preface by Janson Braun. Petrograd: Parus.

Sbornik proletarskikh pisateley 1914. Petrograd: Priboy. 
Scherrer, J. 1980. Un philosophe-ouvrier russe. NE. Vilonov. Le Mouvement Social (111): 165-187.

Sharapov, IP. 1999. 'Kul'turnye lyudi soznatel'no uchityvayut proshloe'. Iz zapisnykh knizhek AA. Bogdanova. Istoricheskiy arkhiv (3).

Sochor, ZA. 1988. Revolution and Culture. The Bogdanov-Lenin Controversy. Ithica and London: Cornell University Press.

Steila, D. 1996. Scienza e rivoluzione. La recezione dell' empiriocriticismo nella cultura russa 1877-1910 Storia della filosofia e del pensiero scientifico. Torino: Universita degli studi di Torino, Fondo di studi Parini-Chirio.

Steila, D. 2013. Nauka i revolyutsyia. Retseptsyia empiriokrititsizma v Russkoy kul'ture 1877-1910 gg. Moscow: Akademicheskiy Proekt.

Steinberg, MD. 2002. Proletarian Imagination. Self, Modernity, and the Sacred in Russia, 1910-1925. Ithica and London: Cornell University Press.

White, JD. 2013. Alexander Bogdanov's Conception of Proletarian Culture. Revolutionary Russia (26): $52-70$.

White, JD. 2019a. Marx and Russia. The Fate of a Doctrine. London: Bloomsbury Academic.

White, JD. 2019b. Red Hamlet. The Life and Ideas of Alexander Bogdanov. Brill: Leiden and Boston.

\section{Authors information}

John Biggart MA, BLitt, PhD. is an independent scholar. He took his first two degrees in the University of Glasgow and his doctorate in the University of East Anglia, where he taught the history of Russia, of Poland, and of the Czechs and Slovaks. In 2000 he diversified into technical assistance in the Russian Federation, working with the Ministry of Finance and the Ministry of Health, mainly in the field of public finance reform. His current projects include: a) A Financial History of Bolshevism; b) The World View of Aleksandr Bogdanov; c) Sergei Stepanovich Chakhotin and the Scientific Organization of Labour. His publications can be found at jbiggart.academia.edu/research.

Christopher Read is Emeritus Professor of History at the University of Warwick. He is writing a history of the Russian intelligentsia, entitled From the Monastery to the Mir Space Station, and an assessment of Lenin's legacy entitled Lenin Lives? in connection with the upcoming centenary of his death.

\section{○ \\ OPEN ACCESS}

Copyright: @ 2021 The Author(s). This is an open-access article distributed under the terms of the CreativeCommons Attribution 4.0 International License (CC-BY 4.0), which permits unrestricted use, distribution, andreproduction in any medium, provided the original author and source are credited. See http://creativecommons.org/licenses/by/4.0/. 